\title{
HYPOCALCEMIA AFTER COMPLETION THYROIDECTOMY FOR PAPILLARY THYROID CARCINOMA
}

\author{
Boris Bumber ${ }^{1}$, Valentino Potroško ${ }^{2}$, Ozren Vugrinec ${ }^{1}$, Maja Ferenčaković ${ }^{3}$, Krešimir Gršić ${ }^{1}$ \\ ${ }^{1}$ Department of Otorhinolaryngology - Head \& Neck Surgery, Zagreb University Hospital Centre, Zagreb, Croatia; \\ ${ }^{2}$ Koprivnica community health center, Koprivnica, Croatia; \\ ${ }^{3}$ Faculty of agriculture, University of Zagreb, Department of Animal Science, Zagreb, Croatia
}

\begin{abstract}
SUMMARY - Surgical management of papillary thyroid carcinoma (PTC) includes total thyroidectomy and lobectomy. After lobectomy, a reoperation called completion thyroidectomy is occasionally required. Postoperative hypocalcemia is the most common complication associated with thyroid surgery. Our main goal was to determine if there is a significant difference between the incidence rate of postoperative hypocalcemia in patients who underwent total thyroidectomy for PTC compared with patients who underwent completion thyroidectomy for PTC. Apart from that, we analyzed the following potential predictive factors for the occurrence of hypocalcemia: sex, age, size of tumor, side of tumor, maximum diameter of individual lobe, occult metastasis, and operating surgeon. The study involved 340 patients who underwent surgery for PTC at the Department of ENT and Head and Neck Surgery, Zagreb University Hospital Centre, between February 25, 2013 and January 3 , 2016. Postoperative hypocalcemia incidence rates were higher in the total thyroidectomy group than in the completion thyroidectomy group (37.8\% and $29.0 \%$, respectively). However, these differences were not statistically significant. Every analyzed potential predictive factor was proven not to have any correlation with postoperative hypocalcemia. This study demonstrated that there was no significant difference between postoperative hypocalcemia rates in patients who underwent completion thyroidectomy compared with patients who underwent total thyroidectomy for PTC.
\end{abstract}

Key words: papillary thyroid carcinoma, total thyroidectomy, completion thyroidectomy, hypocalcemia

\section{Introduction}

Papillary thyroid carcinoma (PTC) is a type of well-differentiated thyroid carcinoma (wDTC), along with follicular and Hürthle cell carcinoma. However, PTC is much more common than the other two types of wDTC, accounting for $70 \%$ to $90 \%$ of all cases of thyroid malignant neoplasms ${ }^{1-4}$. The incidence of PTC was increasing rapidly until the beginning of the last decade, with a female to male ratio of $3: 1^{5}$. The bright side of this high incidence is that PTC is considered to

Corresponding author: Boris Bumber, $M D, P h D$, Department of Otorhinolaryngology - Head \& Neck Surgery, Zagreb University Hospital Centre, Croatia, Zagreb, Kišpatićeva 12

E-mail: borisbumber@yahoo.com be the least aggressive type of thyroid carcinomas ${ }^{5}$. Long-term prognosis is excellent, with survival rates for adults being $90 \%$ at 20 -year follow-up ${ }^{6}$. Contemporary management of PTC consists of primary surgical treatment, postoperative radioiodine therapy, and TSH-suppressive hormonal therapy (based on initial risk stratification and response to therapy on follow up). The extent of the surgery depends on the size of the PTC and associated risk factors. It is recommended that all high-risk patients are treated with total thyroidectomy ${ }^{2,7-9}$. Some guidelines recommend total thyroidectomy in low-risk patients for PTC greater than $4 \mathrm{~cm}$ in diameter, whereas lobectomy is the recommended treatment for smaller PTC ${ }^{7,8}$. On the other hand, others advocate for a more radical approach 
and recommend lobectomy only in low-risk patients with PTC smaller than $1 \mathrm{~cm}$ in diameter ${ }^{2,9}$. However, after lobectomy $5-10 \%$ of patients require a secondary procedure called completion thyroidectomy ${ }^{10,11}$. The indications for completion thyroidectomy after diagnosis of PTC should be the same as for total thyroidectomy ${ }^{12,13}$. Completion thyroidectomy can be performed within 7 days (very early completion thyroidectomy), within 8 days to 3 months (early completion thyroidectomy), or after 3 months from the primary surgery (delayed completion thyroidectomy) ${ }^{14}$.

Until 2016, total thyroidectomy was performed on every patient diagnosed with PTC at our department regardless of the size of the tumor, and completion thyroidectomy was performed on every patient with wDTC diagnosis after initial lobectomy. However, today we perform lobectomy in low-risk patients with PTC smaller than $1 \mathrm{~cm}$. Total and completion thyroidectomy carry a certain risk of permanent and transient complications. In general, the most common complication after thyroid surgery is hypocalcemia caused by transient or permanent hypoparathyroidism $^{15}$. Transient hypoparathyroidism incidences range from $19 \%$ to $47 \%$, and permanent hypoparathyroidism incidences range from $0 \%$ to $30 \%{ }^{15-21}$.

After completion thyroidectomy, transient hypoparathyroidism incidences range from $5 \%$ to $15 \%$ and permanent hypoparathyroidism incidences range from $2 \%$ to $5 \%{ }^{22,23}$. Postoperative hypoparathyroidism usually occurs due to devascularization of parathyroid glands, their inadvertent removal or destruction, or due to formation of hematoma causing their disfunc$\operatorname{tion}^{24,25}$. There are several risk factors associated with the development and greater incidence of hypoparathyroidism after thyroid cancer surgery. Bilateral neck lymph node dissection, gross extrathyroidal extension, and the presence of the parathyroid gland in the pathologic specimen (i.e. inadvertent removal of parathyroid gland) are proven to be significant risk factors for transient and permanent hypoparathyroidism ${ }^{17,26}$. In this study, we decided to investigate the rate of postoperative hypocalcemia after completion thyroidectomy for PTC and compare it with the rate of postoperative hypocalcemia after total thyroidectomy for PTC. Based on previous studies, we expected that the rate for postoperative hypocalcemia will be lower after completion thyroidectomy ${ }^{23}$.

\section{Patients and methods}

This was a retrospective study involving 340 patients who underwent surgery for PTC at the Department of ENT and Head and Neck Surgery, Zagreb University Hospital Centre, between February 25, 2013 and January 3, 2016. Patients who had any preoperative status that could affect postoperative hypocalcemia such as renal insufficiency, elevated PTH as a compensation, or vitamin $\mathrm{D}$ deficiency were excluded from this study. Patients were divided into two groups. The first group included patients who underwent total thyroidectomy, while the second group included $\mathrm{pa}^{-}$ tients who underwent completion thyroidectomy. In this study, we performed total thyroidectomy on patients with PTC, no matter the size. Furthermore, completion thyroidectomy was performed on patients who already underwent lobectomy but were later reoperated due to proven PTC at first surgery or because of previously proven fine needle aspiration biopsy for PTC, follicular/Hürthle tumor, nodes, or goiter in the non-operated lobe. Some patients in both groups were diagnosed with papillary cancer before surgery, while others were diagnosed after surgery. Patients who underwent paratracheal dissection because of the previously proven metastases were excluded from the study. The levels of ionized calcium were measured for all patients the morning after surgery and then every day during hospitalization. Ionized calcium values below 1 $\mathrm{mmol} / \mathrm{L}$ were considered as hypocalcemia as in the study conducted by Paek et al. ${ }^{26}$ Patients were operated on by 6 different surgeons. We investigated the rate of postoperative hypocalcemia, transient and permanent, after completion thyroidectomy and compared it with the rate of postoperative hypocalcemia, transient and permanent, after total thyroidectomy. The criteria for permanent hypocalcemia was the need for calcium replacement six months after surgery. Parameters analyzed as potential predictive factors for the occurrence of hypocalcemia in both groups were: sex, age, size of tumor, side of tumor, maximum diameter of individual lobe, occult metastasis, and operating surgeon. We used Harmonic ACE (Ethicon Endo-Surgery Inc.) in all procedures to reduce operative time ${ }^{27}$. SAS version 9.4 software (Cary, NC: SAS Institute Inc.) was used for statistical analysis. The chi-square test, Student's ttest, and one-way analysis of variance were used to compare the data and the incidence of hypocalcemia. 
Furthermore, binary logistic regression was used to verify the risk factors for hypocalcemia. $\mathrm{P}$ values less than 0.05 were considered statistically significant.

\section{Results}

Patient descriptive statistics and demographics are shown in Table 1 . The majority of the patients were women (84\%). Mean age at time of surgery was 50.1 years, ranging from 14 to 81 . If categorized by age, almost $60 \%$ of patients were below 55 years of age. Following TNM classification, a large proportion of patients (45\%) had a T1a tumor which was followed by T3 (22\%), T1b (19\%), T2 (12\%), and T4 (2\%). Mean maximum diameter of the bigger lobe was $4.61 \mathrm{~cm}$, ranging from 2.00 to $9.00 \mathrm{~cm}$. Mean postoperative calcium level was $1.1 \mathrm{mmol} / \mathrm{L}$, ranging from 0.64 to 1.32 $\mathrm{mmol} / \mathrm{L}$. According to the obtained calcium levels and regardless of the reoperation, 122 (36\%) patients experienced postoperative hypocalcemia, out of which 43 (12.7\%) developed permanent hypocalcemia while the rest recovered. If completion thyroidectomy was performed, the mean time between surgeries was 26.50 months. However, it is important to note that the range was from one to 600 months, and the median (2 months) represents the data far better. Occult metastasis was found in 26 (8\%) patients. Results of the univariate analysis of patient characteristics and total and completion thyroidectomy are presented in Table 2. The analyzed characteristics were sex, age, age group, $\mathrm{T}$-status, maximum diameter of the bigger lobe $(\mathrm{cm})$, side of tumor, post-operative calcium levels (unit), occurrence of hypocalcemia, occurrence of occult metastasis, and operating surgeon. Characteristics for which significant differences were found between patients with total and completion thyroidectomy were T-status $(p=0.010)$, maximum diameter of the bigger lobe $(\mathrm{p}=0.009)$, and postoperative calcium levels $(\mathrm{p}=$ 0.0165 ). Differences in hypocalcemic status were close to significance but they did not pass the threshold ( $\mathrm{p}=$ 0.0557). T1a, T3, and $\mathrm{T} 4$ proportions were found to be higher in the total thyroidectomy group, while $\mathrm{T} 1 \mathrm{~b}$ and $\mathrm{T} 2$ proportions were found to be higher in the completion thyroidectomy group. Differences in mean values between postoperative calcium levels were found to be significant and were higher in the completion thyroidectomy group. Although hypocalcemic
Table 1. Patient characteristics demographics

\begin{tabular}{|c|c|c|c|}
\hline \multicolumn{3}{|l|}{ Variable } & $\begin{array}{l}\text { Total number } \\
\text { of patients }(n=340)\end{array}$ \\
\hline \multirow{2}{*}{\multicolumn{2}{|c|}{ Sex }} & $\mathrm{F}$ & $284(83.5 \%)$ \\
\hline & & M & $56(16.5 \%)$ \\
\hline \multicolumn{2}{|l|}{ Age } & $\begin{array}{l}\text { Mean } \pm \text { SD } \\
\text { (range) }\end{array}$ & $\begin{array}{l}50.06 \pm 14.63 \\
(14-81)\end{array}$ \\
\hline \multirow{2}{*}{\multicolumn{2}{|c|}{ Age groups }} & below 55 & $203(59.7 \%)$ \\
\hline & & above 55 & $137(40.3 \%)$ \\
\hline \multirow{5}{*}{\multicolumn{2}{|c|}{$\mathrm{T}$}} & T1a & $152(44.7 \%)$ \\
\hline & & $\mathrm{T} 1 \mathrm{~b}$ & $65(19.1 \%)$ \\
\hline & & $\mathrm{T} 2$ & $42(12.3 \%)$ \\
\hline & & T3 & $75(22.1 \%)$ \\
\hline & & $\mathrm{T} 4$ & $6(1.8 \%)$ \\
\hline \multicolumn{2}{|c|}{$\begin{array}{l}\text { Maximum } \\
\text { diameter of bigger } \\
\text { lobe }(\mathrm{cm})\end{array}$} & $\begin{array}{l}\text { Mean } \pm \mathrm{SD} \\
\text { (range) }\end{array}$ & $\begin{array}{l}4.61 \pm 1.26 \\
(2.00-9.00)\end{array}$ \\
\hline \multirow{2}{*}{\multicolumn{2}{|c|}{ Side of tumor }} & Left & $158(46.5 \%)$ \\
\hline & & Right & $182(53.5 \%)$ \\
\hline \multicolumn{2}{|c|}{$\begin{array}{l}\text { Post-op calcium } \\
\text { levels }\end{array}$} & $\begin{array}{l}\text { Mean } \pm \text { SD } \\
\text { (range) }\end{array}$ & $\begin{array}{l}1.05 \pm 0.10 \\
(0.64-1.32)\end{array}$ \\
\hline \multirow{3}{*}{$\begin{array}{l}\text { Occurrence of } \\
\text { hypocalcemia }\end{array}$} & & temporary & $79(23.2 \%)$ \\
\hline & yes & permanent & $43(12.7 \%)$ \\
\hline & no & & $218(64.1 \%)$ \\
\hline \multirow{2}{*}{\multicolumn{2}{|c|}{ Reoperation }} & yes & $76(22.3 \%)$ \\
\hline & & no & $264(77.7 \%)$ \\
\hline \multicolumn{2}{|c|}{$\begin{array}{l}\text { Time between two } \\
\text { operation (month) }\end{array}$} & $\begin{array}{l}\text { Mean } \pm \text { SD } \\
\text { (range) } \\
\text { median }\end{array}$ & $\begin{array}{l}26,5 \pm 90,41 \\
(1-600) \\
2\end{array}$ \\
\hline \multirow{2}{*}{\multicolumn{2}{|c|}{ Occult metastasis }} & yes & $26(7.7 \%)$ \\
\hline & & no & $314(92.3 \%)$ \\
\hline \multirow{6}{*}{\multicolumn{2}{|c|}{ Surgeon }} & 1 & $85(25.0 \%)$ \\
\hline & & 2 & $52(15.3 \%)$ \\
\hline & & 3 & $53(15.6 \%)$ \\
\hline & & 4 & $16(4.7 \%)$ \\
\hline & & 5 & $103(30.3 \%)$ \\
\hline & & 6 & $31(9.1 \%)$ \\
\hline
\end{tabular}

status did not pass the significance threshold, it is important to note that the proportion of temporary hypocalcemia was higher for total thyroidectomy (26.1 vs $13.2 \%$ ), while the permanent hypocalcemia proportion was higher for completion thyroidectomy (15.8 vs 11.7 $\%)$. Results of multivariate logistic regression analysis of risk factors associated with the occurrence of post- 
Table 2. Univariate analysis of patient characteristics for total and completion thyroidectomy

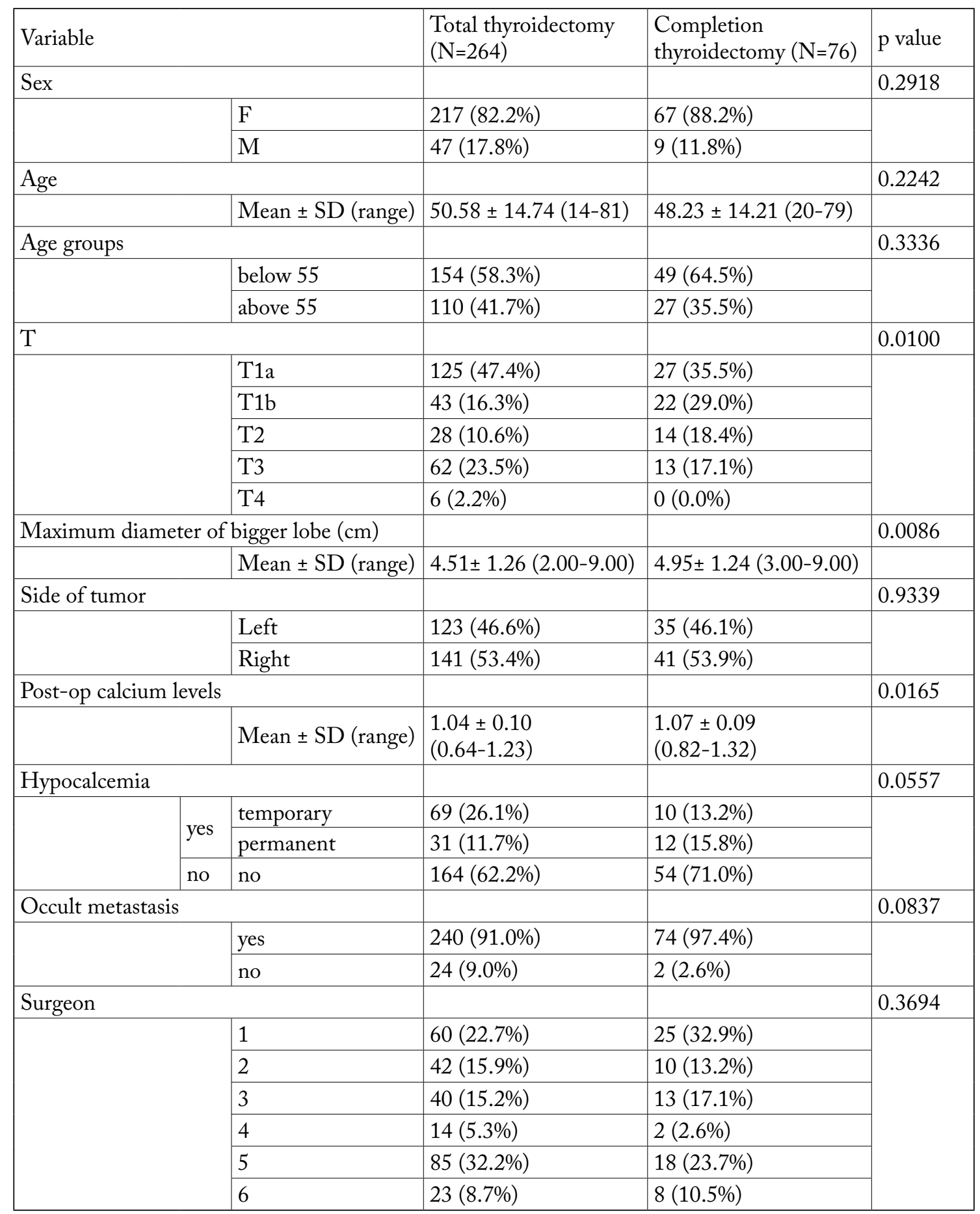

operative hypocalcemia are presented in Table 3. We tested a model presuming that sex, age, age group, Tstatus, maximum diameter of the bigger lobe, side of the tumor, reoperation, occurrence of occult metasta- sis, and operating surgeon can predict if hypocalcemia will occur or not. The model ended up being not significant ( $p=0.3486)$. However, it is worth noting that the odds of hypocalcemia were somewhat higher for 
Table 3. Multivariate logistic regression analysis of risk factors associated with postoperative bypocalcemia

\begin{tabular}{|c|c|c|c|c|c|}
\hline \multirow{2}{*}{\multicolumn{2}{|c|}{ Variables }} & & \multicolumn{2}{|c|}{ 95\% Confidence interval } & \multirow[b]{2}{*}{$p$ value } \\
\hline & & Odds ratio & Lower & Upper & \\
\hline \multicolumn{2}{|l|}{$\operatorname{Sex}(F)$} & 1.0828 & 0.5790 & 2.0250 & 0.8033 \\
\hline \multicolumn{2}{|l|}{ Age $^{*}$} & 1.0078 & 0.9795 & 1.0368 & 0.5937 \\
\hline \multicolumn{2}{|l|}{ Age group (above 55) } & 0.9421 & 0.4154 & 2.1368 & 0.8865 \\
\hline \multirow[t]{4}{*}{$\mathrm{T}(\mathrm{T} 1 \mathrm{a})$} & $\mathrm{T} 1 \mathrm{~b}$ & 0.9191 & 0.4817 & 1.7539 & 0.7982 \\
\hline & $\mathrm{T} 2$ & 1.4281 & 0.6449 & 3.1635 & 0.3799 \\
\hline & T3 & 0.8667 & 0.4773 & 1.5740 & 0.6385 \\
\hline & $\mathrm{T} 4$ & 0.1853 & 0.0302 & 1.1376 & 0.0687 \\
\hline \multicolumn{2}{|c|}{ Maximum diameter of bigger lobe } & 1.1973 & 0.9904 & 1.4473 & 0.0628 \\
\hline Side of tumor (Left) & Right & 0.7519 & 0.4700 & 1.2030 & 0.2344 \\
\hline \multicolumn{2}{|c|}{ Occult metastasis (yes) } & 0.5485 & 0.2103 & 1.4308 & 0.2196 \\
\hline \multicolumn{2}{|c|}{ Completion thyroidectomy } & 0.6760 & 0.3736 & 1.2229 & 0.1954 \\
\hline \multirow[t]{5}{*}{ Surgeon (1) } & 2 & 0.5807 & 0.2693 & 1.2524 & 0.1658 \\
\hline & 3 & 0.6476 & 0.3014 & 1.3918 & 0.2657 \\
\hline & 4 & 0.7018 & 0.2191 & 2.2481 & 0.5511 \\
\hline & 5 & 0.5268 & 0.2745 & 1.0113 & 0.0541 \\
\hline & 6 & 1.0052 & 0.3923 & 2.5757 & 0.9914 \\
\hline
\end{tabular}

* per unit of change in regressor

Table 4. Multivariate logistic regression analysis of risk factors associated with permanent bypocalcemia (n/a-not estimable)

\begin{tabular}{|c|c|c|c|c|c|}
\hline \multirow{2}{*}{\multicolumn{2}{|c|}{ Variables }} & & \multicolumn{2}{|c|}{ 95\% Confidence interval } & \multirow[b]{2}{*}{$\mathrm{p}$ value } \\
\hline & & Odds ratio & Lower & Upper & \\
\hline \multicolumn{2}{|l|}{$\operatorname{Sex}(F)$} & 0.3599 & 0.0961 & 1.3476 & 0.1293 \\
\hline \multicolumn{2}{|l|}{$\mathrm{Age}^{*}$} & 0.9811 & 0.9265 & 1.0389 & 0.5142 \\
\hline \multicolumn{2}{|l|}{ Age group (above 55) } & 0.8876 & 0.1842 & 4.2775 & 0.8818 \\
\hline \multirow{4}{*}{$\mathrm{T}(\mathrm{T} 1 \mathrm{a})$} & T1b & 0.4144 & 0.1178 & 1.4575 & 0.1698 \\
\hline & $\mathrm{T} 2$ & 0.5957 & 0.1169 & 3.0362 & 0.5330 \\
\hline & T3 & 2.1489 & 0.5694 & 8.1104 & 0.2590 \\
\hline & $\mathrm{T} 4$ & $\mathrm{n} / \mathrm{a}$ & $\mathrm{n} / \mathrm{a}$ & $\mathrm{n} / \mathrm{a}$ & $\mathrm{n} / \mathrm{a}$ \\
\hline \multicolumn{2}{|c|}{ Maximum diameter of bigger lobe } & 0.8418 & 0.5466 & 1.2964 & 0.4344 \\
\hline Side of tumor (Left) & Right & 0.7742 & 0.3022 & 1.9834 & 0.5936 \\
\hline \multicolumn{2}{|l|}{ Occult metastasis (yes) } & $\mathrm{n} / \mathrm{a}$ & $\mathrm{n} / \mathrm{a}$ & $\mathrm{n} / \mathrm{a}$ & $\mathrm{n} / \mathrm{a}$ \\
\hline \multicolumn{2}{|c|}{ Completion thyroidectomy } & 2.6133 & 0.8173 & 8.3554 & 0.1053 \\
\hline \multirow[t]{5}{*}{ Surgeoon (1) } & 2 & 1.0835 & 0.2518 & 5.5259 & 0.8340 \\
\hline & 3 & 0.5592 & 0.1699 & 2.5991 & 0.5570 \\
\hline & 4 & 1.9280 & 0.1449 & 20.580 & 0.6657 \\
\hline & 5 & 2.2243 & 0.6453 & 7.5517 & 0.2070 \\
\hline & 6 & 2.5562 & 0.4168 & 20.641 & 0.2797 \\
\hline
\end{tabular}

(n/a - estimate not possible) 
female patients and increased with age (per unit of change in regressor) and maximum diameter of the bigger lobe. T1a status of the tumor was also associated with lower odds, except when compared with T2 status when there was a bigger chance of onset of hypocalcemia. If the tumor was located on the left side, the chances were lower. These results are speculative and cannot be considered as predictors because they did not reach statistical significance. Multivariate logistic regression analysis was also used for determining risk factors for permanent hypocalcemia in 122 hypocalcemic cases, and the results are presented in Table 4. The model was the same as the one described above and was significant $(p=0.0028)$. However, none of the factors alone passed the threshold in Wald test. Estimated odds ratios were also not significant.

\section{Discussion}

Postoperative hypocalcemia is of great concern for all surgeons performing thyroidectomy. It is the most common postoperative complication associated with thyroid surgery. It is mostly caused by transient hypoparathyroidism and less frequently by permanent hypoparathyroidism (hypocalcemia lasting longer than 6 months) that can develop after total thyroidectomy, lobectomy, or completion thyroidectomy ${ }^{28}$. Surgical management of PTC is still a subject of controversy. As already mentioned in the introduction, there is still no uniform opinion on when total thyroidectomy versus lobectomy is recommend for treating $\mathrm{PTC}^{2,7-9,29}$. Over the duration of this study, we performed total thyroidectomy on patients with PTC regardless of the size of the tumor. Completion thyroidectomy was performed on patients who already underwent lobectomy but were later reoperated. Primary indication for completion thyroidectomy for some patients was not PTC, but one of the following: follicular carcinoma, Hurtle cell tumor, nodes, or goiter. However, histopathological analysis demonstrated that they all had PTC in their sample. The main goal of this study was to determine if there was a significant difference between the incidence of postoperative hypocalcemia in patients who underwent total thyroidectomy for PTC compared with patients who underwent completion thyroidectomy for PTC. The study demonstrated that there was no statistically significant difference in the incidence rates of postoperative hypocalcemia between the two groups. The group that underwent total thyroidectomy had $37.8 \%$ of patients with postoperative hypocalcemia while the group that underwent completion thyroidectomy had $29.0 \%$. There have been only a few studies on this subject. As in our study, Li et al. demonstrated that there was no significant difference between hypocalcemia rates in completion the thyroidectomy and total thyroidectomy groups ${ }^{30}$. In contrast, Merchavy et al. demonstrated that there was a significantly lower risk of postoperative hypocalcemia after completion thyroidectomy ${ }^{31}$. The incidence of hypocalcemia after total thyroidectomy was found to be lower in some other studies, varying from $12 \%$ to $31 \% 17,23,25,31,32$. However, some meta-analyses show that it can vary from $30 \%$ to $60 \%{ }^{33}$. Likewise, the incidence of hypocalcemia after completion thyroidectomy is also lower in most other studies we investigated, varying from $1 \%$ to $18 \%{ }^{23,30,31}$. These differences may be due to different ways of defining hypocalcemia. In addition, we found that transient hypocalcemia was more prevalent after total thyroidectomy than the in completion thyroidectomy group $(26.1 \%$ and $13.2 \%$, respectively), while permanent hypocalcemia was more frequent in the completion thyroidectomy group than in the total thyroidectomy group (15.8\% and $11.7 \%$, respectively). However, those differences were not statistically significant. Li et al. did not report the results in agreement with ours. In their study, both transient and permanent hypocalcemia were more represented in the total thyroidectomy group ${ }^{30}$. In the study conducted by Merhchavy et al., there were no cases of permanent hypocalcemia, but transient hypocalcemia was more frequent in the total thyroidectomy group ${ }^{31}$. Based on our research and other studies, we can conclude that transient hypocalcemia is more common after total thyroidectomy. The rates of permanent hypocalcemia in both total the thyroidectomy and completion thyroidectomy groups $(11.8 \%, 15.8 \%$, respectively) were notably higher in this study when compared with other studies where those rates vary from $0.0 \%$ to $2.8 \% 17,25,30,31$. Even though there was no significant difference between rates of hypocalcemia in the total thyroidectomy and the completion thyroidectomy group, postoperative calcium levels were slightly lower in the total thyroidectomy group. This study demonstrated that tumor size was not in correlation with hypocalcemia rates, which is in concordance with studies by Cho et al. and Lee et al. ${ }^{34,35}$ However, we 
determined significant differences in hypocalcemia rates after total thyroidectomy and completion thyroidectomy in patients with the same T stage (TNM classification). Additionally, we analyzed if the dimension of the biggest thyroid lobe was related to postoperative hypocalcemia, but there was no statistically significant correlation. However, the incidence of hypocalcemia was somewhat higher and increased with the diameter of the bigger lobe. Mejia et al. demonstrated a positive correlation between preoperative thyroid gland size and hypocalcemia ${ }^{36}$. The surgeons in this study differed in experience and in annual surgical volume. As reported in previous studies, we expected that there would be a significant difference between hypocalcemia rates between patients operated by different surgeons $s^{37,38}$. However, we found that postoperative hypocalcemia rates in our institution did not depend on the surgeon who performed the total thyroidectomy or completion thyroidectomy procedure. This study showed that sex was not an independent risk factor for post-thyroidectomy hypocalcemia, which is in contrast with studies by Rogerio et al. and Poch et al. They proved that female sex was more susceptible to postoperative hypocalcemia after total thyroidectomy 33,39. However, Nair et al. also did not find that female sex affects hypocalcemia rates ${ }^{40}$. Age was another factor that this study found not to correlate with postthyroidectomy hypocalcemia rates. In the literature, there are contrasting opinions about the correlation between the development of post-thyroidectomy hypocalcemia and patient age. Some have found that hypocalcemia is associated with younger age, whereas some have found an association with advanced age ${ }^{41}$. As in our study, Edafe et al. also reported no significant correlation between age and hypocalcemia after thyroidectomy ${ }^{42}$. Existence of occult metastasis was also not correlated with post-thyroidectomy hypocalcemia. There are no other studies that investigated this correlation. Similarly, our study found that the hypocalcemia rates after total thyroidectomy are not in correlation with the side of thyroid gland infiltrated with PTC. There are no published studies concerning the aforementioned factor. In our study, 22 patients had hypocalcemia after completion thyroidectomy, 10 of whom had temporary and 12 of whom had permanent hypocalcemia. We analyzed whether the time of reoperation was correlated with developing temporary or permanent hypocalcemia, but we found no significant correlation. On the one hand, it is possible that time from first lobectomy and time for recovery of the parathyroid on that side of the neck could affect whether the patient will develop temporary or permanent hypocalcemia. On the other hand, that could be affected only by how the second lobectomy is performed. Obviously, it could also be affected by both of these factors. However, our analysis does not show evidence for any of that, perhaps because operations were performed by different surgeons. Finally, we must mention vitamin $\mathrm{D}$, an important factor for postoperative hypocalcemia after thyroid surgery. Some studies have demonstrated that deficient levels of preoperative vitamin $\mathrm{D}$ are a significant risk factor for transient postoperative hypoparathyroidism after thyroid surgery. Therefore, they propose preoperative supplementation of vitamin $\mathrm{D}$ in order to minimize the risk of hypocalcemia $^{43-45}$.

\section{Conclusion}

This study proved that there is no significant difference between postoperative hypocalcemia rates in $\mathrm{pa}$ tients who underwent completion thyroidectomy compared with patients who underwent total thyroidectomy for PTC. In other words, this study demonstrates that completion thyroidectomy is as safe as total thyroidectomy for management of PTC with regard to postoperative hypocalcemia. Size of PTC, preoperative dimension of the biggest thyroid lobe, surgeon experience, annual surgical volume, gender, age, occult metastasis were not proved as significant risk factors for postoperative hypocalcemia.

\section{Acknowledgments}

None.

\section{References}

1. Haymart MR, Esfandiari NH, Stang MT, Sosa JA. Controversies in the management of low-risk differentiated thyroid cancer. Endocr Rev. 2017;38(4):351-78. doi:10.1210/er.201700067

2. Dralle H, Musholt TJ, Schabram J, Steinmüller T, Frilling A, Simon D, et al. German Association of Endocrine Surgeons practice guideline for the surgical management of malignant thyroid tumors. Langenbeck's Arch Surg. 2013;398(3):347-75. doi:10.1007/s00423-013-1057-6 
3. Rajjoub SR, Yan H, Calcatera NA, Kuchta K, Wang C-HE, Lutfi W, et al. Thyroid lobectomy is not sufficient for T2 papillary thyroid cancers. Surgery. 2018;163(5):1134-43. doi: 10.1016/j.surg.2017.12.026

4. Blažeković I, Jukić T, Granić R, Punda M, Franceschi M. An Unusual Case of Papillary Thyroid Carcinoma Iodine-131 Avid Metastasis to the Adrenal Gland. Acta Clin Croat. 2018; 57(2):372-6. doi:10.20471/acc.2018.57.02.20

5. Vasileiadis I, Boutzios G, Karalaki M, Misiakos E, Karatzas T. Papillary thyroid carcinoma of the isthmus: Total thyroidectomy or isthmusectomy? Am J Surg. 2018;216(1):135-9. doi: 10.1016/j.amjsurg.2017.09.008

6. Ito Y, Miyauchi A, Kihara M, Fukushima M, Higashiyama T, Miya A. Overall Survival of Papillary Thyroid Carcinoma Patients: A Single-Institution Long-Term Follow-Up of 5897 Patients. World J Surg. 2018;42(3):615-22. doi:10.1007/s00 268-018-4479-z

7. Mitchell AL, Gandhi A, Scott-Coombes D, Perros P. Management of thyroid cancer: United Kingdom National Multidisciplinary Guidelines. J Laryngol Otol. 2016;130(Supl. 2):15060. doi:10.1017/S0022215116000578

8. Haugen BR, Alexander EK, Bible KC, Doherty GM, Mandel SJ, Nikiforov YE, et al. 2015 American Thyroid Association Management Guidelines for Adult Patients with Thyroid Nodules and Differentiated Thyroid Cancer: The American Thyroid Association Guidelines Task Force on Thyroid Nodules and Differentiated Thyroid Cancer. Thyroid. 2016;26(1):1-133. doi:10.1089/thy.2015.0020

9. Pacini F, Schlumberger M, Dralle H, Elisei R, Smit JWA, Wiersinga W, et al. European consensus for the management of patients with differentiated thyroid carcinoma of the follicular epithelium. Eur J Endocrinol. 2006;154(6):787-803. doi:10.1530/eje.1.02158

10. Kisaoğlu A, Özoğul B, Akçay MN, Öztörk G, Atamanalp SS, Aydinli B, et al. Completion thyroidectomy in differentiated thyroid cancer: When to perform? Turkish J Surg. 2014;30 (1):18-21. doi:10.5152/UCD.2014.2486

11. Shaha AR, Michael Tuttle R. Completion thyroidectomy-indications and complications. Eur J Surg Oncol. 2019;45 (7):1129-31. doi:10.1016/j.ejso.2019.03.028

12. Varaldo E, Ansaldo GL, Assalino M, Massobrio A, Torre GC, Borgonovo Giacomo G. Completion thyroidectomy for differentiated thyroid cancer (Results in a Consecutive Series of 68 Patients). Acta Chir Belg. 2012;112(1-2):40-3. doi:10.1080/0 0015458.2012.11680793

13. Makay O, Unalp O, Icoz G, Akyildiz M, Yetkin E. Completion thyroidectomy for thyroid cancer. Acta Chir Belg. 2006; 106(5):528-31. doi:10.1080/00015458.2006.11679945

14. Saleem R Bin, Saleem M Bin, Saleem N Bin. Impact of completion thyroidectomy timing on post-operative complications: A systematic review and meta-analysis. Gland Surg. 2018;7 (5):458-65. doi:10.21037/gs.2018.09.03

15. Coimbra C, Monteiro F, Oliveira P, Ribeiro L, de Almeida MG, Condé A. Hipoparatiroidismo tras tiroidectomía: factores predictivos. Acta Otorrinolaringol Esp. 2017;68(2):106-11. doi:10.1016/j.otorri.2016.06.008

16. Park I, Rhu J, Woo JW, Choi JH, Kim JS, Kim JH. Preserving Parathyroid Gland Vasculature to Reduce Post-thyroidectomy Hypocalcemia. World J Surg. 2016;40(6):1382-9. doi:10.1007/ s00268-016-3423-3

17. Lee YS, Nam KH, Chung WY, Chang HS, Park CS. Postoperative complications of thyroid cancer in a single center experience. J Korean Med Sci. 2010;25(4):541-5. doi:10.3346/ jkms.2010.25.4.541

18. Olson JA, Debenedefti MK, Baumann DS, Wells SA, Olson Jr JA, DeBenedetti MK, et al. Parathyroid Autotranspiantation During Thyroidectomy Results of Long-Term Follow-Up. Ann Surg. 1996;223(5):472-80. doi:10.1097/00000658-1996 05000-00003

19. Grabovac S, Prgomet D, Janjanin S, Hadzibegović A. Parathyroid hormone values in thyroid gland surgeries by harmonic scalpel and by conventional methods. Liječnički Vjesn. 2013; 135(11-12):306-10.

20. Radivojević RC, Prgomet D, Markesić J, Ezgeta C. Hypocalcaemia after thyroid surgery for differentiated thyroid carcinoma: preliminary study report. Coll Antropol. 2012;36 (Supl. 2):73-8.

21. Kusić Z, Prgomet D. Karcinom štitne i doštitne žlijezde. In: Prgomet D, editor. Tumori glave i vrata. Zagreb: Medicinska naklada; 2019. p. 262-73.

22. Eroğlu A, Berberoğlu U, Buruk F, Yildirim E. Completion thyroidectomy for differentiated thyroid carcinoma. J Surg Oncol. 1995;59(4):261-7. doi:10.1002/jso.2930590413

23. Rafferty MA, Goldstein DP, Rotstein L, Asa SL, Panzarella T, Gullane P, et al. Completion thyroidectomy versus total thyroidectomy: is there a difference in complication rates? An analysis of 350 patients. J Am Coll Surg. 2007;205(4):602-7. doi:10.1016/j.jamcollsurg.2007.05.030

24. Testini M, Gurrado A, Lissidini G, Nacchiero M. Hypoparathyroidism after total thyrodectomy. Minerva Chir. 2007;62 (5):409-15. doi:10.1001/archsurg.2007.55

25. Almquist M, Hallgrimsson P, Nordenström E, Bergenfelz A, Hallgrimsson $\bullet$ P, Nordenström $\bullet E$, et al. Prediction of Permanent Hypoparathyroidism after Total Thyroidectomy. World J Surg. 2015;38(10):2613-20. doi:10.1007/s00268-014-2622-z

26. Paek SH, Lee YM, Min SY, Kim SW, Chung KW, Youn YK. Risk factors of hypoparathyroidism following total thyroidectomy for thyroid cancer. World J Surg. 2013;37(1):94-101. doi: 10.1007/s00268-012-1809-4

27. Prgomet D, Janjanin S, Bilić M, Prstacić R, Kovac L, Rudes M, et al. A prospective observational study of 363 cases operated with three different harmonic scalpels. Eur Arch Othorinolaryngol. 2009;266(12):1965-70. doi:10.1007/s00405-009-0954-3

28. Tredici P, Grosso E, Gibelli B, Massaro MA, Arrigoni C, Tradati N. Identification of patients at high risk for hypocalcemia after total thyroidectomy. Acta Otorhinolaryngol Ital. 2011; 31(3):144-8. 
29. Santini J, Haddad A. Total thyroidectomy is the recommended treatment for all Papillary Thyroid Carcinoma (PTC). Acta Otorhinolaryngol Belg. 1999;53(3):161-4.

30. Li Y-J, Wang Y-Z, Yi Z-B, Chen L-L, Zhou X-D. Comparison of Completion Thyroidectomy and Primary Total Surgery for Differentiated Thyroid Cancer: A Meta-Analysis. Oncol Res Treat. 2015;38(10):528-31. doi:10.1159/000440690

31. Merchavy S, Marom T, Forest V-I, Hier M, Mlynarek A, $\mathrm{McHugh} \mathrm{T}$, et al. Comparison of the incidence of postoperative hypocalcemia following total thyroidectomy vs completion thyroidectomy. Otolaryngol Head Neck Surg. 2015;152(1): 53-6. doi:10.1177/0194599814556250

32. Asari R, Passler C, Kaczirek K, Scheuba C, Niederle B. Hypoparathyroidism After Total Thyroidectomy: A Prospective Study. Arch Surg. 2008;143(2):132-7. doi:10.1001/archsurg. 2007.55

33. Dedivitis RA, Aires FT, Cernea CR. Hypoparathyroidism after thyroidectomy: Prevention, assessment and management. Curr Opin Otolaryngol Head Neck Surg. 2017;25(2):142-6. doi:10.1097/MOO.0000000000000346

34. Cho JN, Park WS, Min SY. Predictors and risk factors of hypoparathyroidism after total thyroidectomy. Int J Surg. 2016;34: 47-52. doi:10.1016/j.ijsu.2016.08.019

35. Lee Y, Cho JY, Sung T-Y, Kim TY, Chung K-W, Hong SJ, et al. Clinicopathological Risk Factors and Biochemical Predictors of Safe Discharge after Total Thyroidectomy and Central Compartment Node Dissection for Thyroid Cancer: A Prospective Study. Wall JR, editor. Int J Endocrinol [Internet]. 2015;2015:214525. doi:10.1155/2015/214525: https://doi.org $/ 10.1155 / 2015 / 214525$

36. Mejia M, Gonzalez-Devia D, Fierro F, Tapiero M, Rojas L, Cadena-Pineros E. Hypocalcemia posthyroidectomy: prevention, diagnosis and management. J Transl Sci. 2018;4(2):1-7. doi:10.15761/jts.1000212

37. Duclos A, Peix J-LL, Colin C, Kraimps J-LL, Menegaux F, Pattou FF, et al. Influence of experience on performance of individual surgeons in thyroid surgery: prospective cross sectional multicentre study. Br Med J (Clin Res Ed). 2012;344(7843): d8041. doi:10.1136/bmj.d8041

38. Meltzer C, Hull M, Sundang A, Adams JL. Association between Annual Surgeon Total Thyroidectomy Volume and Transient and Permanent Complications. JAMA Otolaryngol - Head Neck Surg. 2019;145(9):830-7. doi:10.1001/jamaoto. 2019.1752

39. Lorente-Poch L, Sancho JJ, Ruiz S, Sitges-Serra A. Importance of in situ preservation of parathyroid glands during total thyroidectomy. Br J Surg. 2015;102(4). doi:10.1002/bjs.9676

40. Nair Cg, Babu MC, Menon R, Jacob P. Hypocalcaemia following total thyroidectomy: An analysis of 806 patients. Indian J Endocrinol Metab. 2013;17(2):298. doi:10.4103/2230-8210. 109718

41. Del Rio P, Rossini M, Montana CM, Viani L, Pedrazzi G, Loderer T, et al. Postoperative hypocalcemia: Analysis of factors influencing early hypocalcemia development following thyroid surgery. BMC Surg. 2019;18(Supl.1):25. doi:10.1186/s12893019-0483-y

42. Edafe O, Balasubramanian SP. Incidence, prevalence and risk factors for post-surgical hypocalcaemia and hypoparathyroidism. Gland Surg. 2017;6(Supl. 1):59-68. doi:10.21037/gs. 2017.09.03

43. de Carvalho GB, Giraldo LR, Lira RB, Macambira IBM, Tapia $\mathrm{MA}$, Kohler HF, et al. Preoperative vitamin D deficiency is a risk factor for postoperative hypocalcemia in patients undergoing total thyroidectomy: Retrospective cohort study. Sao Paulo Med J. 2019;137(3):241-7. doi:10.1590/1516-3180.2018. 0336140319

44. Tripathi M, Karwasra RK, Parshad S. Effect of preoperative vitamin $\mathrm{D}$ deficiency on postoperative hypocalcemia after thyroid surgery. Thyroid Res. 2014;7(1). doi:10.1186/1756-6614-7-8

45. Danan D, Shonka DCJ. Preoperative vitamin D level as predictor of post-thyroidectomy hypocalcemia in patients sustaining transient parathyroid injury. Head Neck. 2017;39(7):1378-81. doi:10.1002/hed.24775 
Sažetak

\section{HIPOKALCIJEMIJA NAKON “COMPLETION”TIREOIDEKTOMIJE ZBOG PAPILARNOG KARCINOMA ŠTITNJAČE}

\section{B. Bumber, V. Potroško, O. Vugrinec, M. Ferenčaković i K. Gršič}

Kirurška terapija papilarnog karcinoma štitnjače obuhvaća totalnu tireoidektomiju i lobektomiju. Katkad je nakon lobektomije potrebno napraviti reoperaciju koja se naziva „completion“ tireoidektomija. Postoperativna hipokalcijemija najčešća je komplikacija povezana s kirurgijom štitnjače. Cilj našeg rada bio je utvrditi postoji li značajna razlika u učestalosti postoperativne hipokalcijemije kod pacijenata koji su bili podvrgnuti totalnoj tireoidektomiji zbog papilarnog karcinoma štitnjače i pacijenata kod kojih je rađena „completion“ tireoidektomija zbog papilarnog karcinoma štitnjače. Osim toga analizirali smo sljedeće potencijalne prediktivne faktore za pojavu hipokalcijemije: spol, dob, veličina tumora, strana tumora, maksimalni promjer pojedinačnog režnja, okultne metastaze i kirurg. U istraživanje je bilo uključeno 340 pacijenata operiranih zbog papilarnog karcinoma štitnjače na Klinici za bolesti uha, grla i nosa i kirurgiju glave i vrata, KBC Zagreb, u razdoblju od 25. veljače 2013. do 3. siječnja 2016. Učestalost hipokalcijemije nakon totalne tirodektomije bila je veća, 37, 8\% u usporedbi s $29 \%$ nakon „completion“ tireoidektomije. Unatoč tome, ta razlika nije bila statistički značajna. Nijedan od analiziranih faktora nije doveden u korelaciju s postoperativnom hipokalcijemijom. Naše je istraživanje pokazalo da ne postoji značajna razlika u učestalosti postoperativne hipokalcijemije između pacijenata podvrgnutih "completion“ tireoidektomiji i pacijenata podvrgnutih totalnoj tireoidektomiji zbog papilarnog karcinoma štitnjače.

Ključne riječi: papilarni karcinom štitnjače, totalna tireoidektomija, "completion"tireoidektomija, hipokalcijemija 